\title{
Internet of Things: Comparative Study on Classification Algorithms (k-NN, Naive Bayes and Case based Reasoning)
}

\author{
Roshna Chettri \\ Sikkim Manipal Institute of \\ Technology. \\ Sikkim Manipal University
}

\author{
Shrijana Pradhan \\ Sikkim Manipal Institute of \\ Technology. \\ Sikkim Manipal University
}

\author{
Lekhika Chettri \\ Sikkim University \\ Gangtok
}

\begin{abstract}
The Internet of Things aims to connect each existing things in the world with internet. It is sweeping all the things to a world like a garland where each flower is connected by a sting forming connectivity. IoT can be considered as a big bucket where everything's, every data in the world can be poured to form a live-like connectivity, and hence needs data computation for prediction of the unknown data. Data computation in the internet of things is incorporated to return the value data from the huge collected data collected from the different sources device of the IoT. There are various algorithms for computation of data. This paper focus on comparing supervised learning algorithms i.e. K-NN, Naive Bayes and Cased Based Reasoning (CBR) Classifier.The effects of the mentioned algorithms are based on the following parameters i.e. size of the dataset, performance, processing time and accuracy.
\end{abstract}

\section{Keywords}

K-NN, Naive Bayes, Case Based Reasoning.

\section{INTRODUCTION}

In classification, a classifier is learned from a set of training examples with class labels. The performance of a classifier is determined by its classification accuracy. Classification techniques in data mining are capable of processing a large amount of data. It can predict class labels and classifies data based on training set and class labels and therefore can be used for classifying unseen available data.

\section{CLASSIFICATION ALGORITHM}

\subsection{K- Nearest Neighbors Classification}

$\mathrm{K}$ Nearest Neighbors is a simple algorithm that stocks all existing cases and classifies new cases/data based on a similar measure (e.g., distance functions). It has been widely used for decades as an effective classification mode. It assumes that the data is in a feature space. The data can be scalars or possibly even multidimensional vectors. $\mathrm{K}$ decides how many neighbors (neighbor is defining on the base of distance metric) influence the classification. [5] This is usually an odd number say if the number of classes is 2 then $k=1$ and the algorithm is simply called the nearest neighbor algorithm. Choice of $\mathrm{k}$ is very acute [8] - A small value of $\mathrm{k}$ means that noise will have a higher influence on the result. A large value makes it computationally expensive and can defeats the basic philosophy behind KNN.

\section{Description of an algorithm}

Example1: In this example a factory produce a new paper so without survey we can identify whether that paper will be good or bad. Using k-NN the following steps are followed to identify paper classification.

\subsubsection{Training set: $(x 1, y 1),(x 2, y 2), \ldots,(x n, y n)$}

The training data are stored in advance. This data is used for determining the accuracy of the algorithm and classifying. Referring to this training data unknown data are identified and are classified.

Table 1: Data set for training data

\begin{tabular}{|c|c|c|}
\hline X1= Acid durability & $\begin{array}{c}\mathbf{X 2}= \\
\text { Strength }\end{array}$ & Y=Classification \\
\hline 5 & 5 & Bad \\
\hline 8 & 5 & Bad \\
\hline 3 & 5 & Good \\
\hline 7 & 5 & Good \\
\hline
\end{tabular}

Consider $\mathrm{x} 1=3$ and $\mathrm{x} 2=7$.

$\mathrm{K}=3$.

\subsubsection{Calculate distance:}

Calculate the distance between the query-instances and all the training data.

Table 2: Distance Calculation.

\begin{tabular}{|c|}
\hline Distance calculation $(\mathbf{X}-\mathbf{x} 1)^{\mathbf{2}}+(\mathbf{x} 2-\mathbf{X} 2)^{\mathbf{2}}$ \\
\hline$(5-3)^{2}+(5-7)^{2}=8$ \\
\hline 29 \\
\hline 4 \\
\hline 20 \\
\hline
\end{tabular}

\subsubsection{Determine nearest neighbor}

Sort the distance to determine the nearest neighbor based on the kth minimum distance.

Table 3: Sorting Nearest Neighbor

\begin{tabular}{|c|c|c|}
\hline $\begin{array}{c}\text { Distance } \\
\text { calculation }\end{array}$ & $\begin{array}{c}\text { Rank minimum } \\
\text { distance }\end{array}$ & $\begin{array}{c}\text { Is it included in 3 } \\
\text { nearest neighbor }\end{array}$ \\
\hline 8 & 2 & Yes \\
\hline 29 & 4 & No \\
\hline 4 & 1 & Yes \\
\hline 20 & 3 & Yes \\
\hline
\end{tabular}




\subsubsection{Gather the category $Y$ of the nearest neighbor}

Table4: category $Y$ of the nearest neighbor.

\begin{tabular}{|l|l|l|l|l|l|}
\hline $\begin{array}{l}\text { X= } \\
\text { Acid } \\
\text { durabil } \\
\text { ity }\end{array}$ & $\begin{array}{l}\text { X2= } \\
\text { Stren } \\
\text { gth }\end{array}$ & $\begin{array}{l}\text { Distanc } \\
\text { e } \\
\text { calculati } \\
\text { on }\end{array}$ & $\begin{array}{l}\text { Ran } \\
\mathbf{k} \\
\text { mini } \\
\mathbf{m u} \\
\mathbf{m} \\
\text { dista } \\
\text { nce }\end{array}$ & $\begin{array}{l}\text { Is it } \\
\text { included } \\
\text { in 3 } \\
\text { nearest } \\
\text { neighbor }\end{array}$ & Y \\
\hline 5 & 5 & 8 & 2 & Yes & Bad \\
\hline 8 & 5 & 29 & 4 & No & - \\
\hline 3 & 5 & 4 & 1 & Yes & Good \\
\hline 7 & 5 & 20 & 3 & Yes & Good \\
\hline
\end{tabular}

\subsubsection{Use simple majority of the category of the} nearest neighbors as the prediction of the query instance

We have seen that there are 2 good and 1 bad.

Predications is based on majority of votes and since there are two votes for good and one vote for bad. Therefore it concludes that paper the factory produce is good.

\subsection{Naive Bayes classifier}

Naive Bayes classification aim is to construct a rule which will allow assigning future objects to a class, given only the vectors of variables describing the future objects. To use this to produce classifications, we need to early estimation and training dataset. After that calculate all the possible probability of the given dataset. When new data arrive for classification then with the reference to priori calculated probability and training dataset it provide the final result indicating which class does the unseen data fall.

\section{Description of algorithm}

Example2: In this example for given dataset it tries to find either a tuple $\mathrm{x}$ buys a mobile phone or not.

\subsubsection{D: Set of tuples}

Each Tuple is an 'n' dimensional attribute vector

$$
\mathrm{X}:(\mathrm{x} 1, \mathrm{x} 2, \mathrm{x} 3, \ldots, \mathrm{xn})
$$

$\mathrm{X}=($ income $=$ medium, credit rating $=$ fair $)$

Table1: Dataset.

\begin{tabular}{|c|c|c|c|}
\hline Record no & $\begin{array}{c}\text { Credit } \\
\text { rating }\end{array}$ & Income & $\begin{array}{c}\text { Buys } \\
\text { mobile }\end{array}$ \\
\hline R1 & Good & High & Yes \\
\hline R2 & Fair & Medium & No \\
\hline R3 & Excellent & High & Yes \\
\hline R4 & Fair & Medium & Yes \\
\hline
\end{tabular}

\subsubsection{Determined a priori probability for each}

class.

Probability for a feature vector is calculated.

$\mathrm{X}=($ income $=$ medium, credit rating $=$ fair $)$

$\mathrm{P}(\mathrm{X} / \mathrm{Ci})=\mathrm{P}(\mathrm{x} 1 / \mathrm{Ci}) * \mathrm{P}(\mathrm{x} 2 / \mathrm{Ci}) * \ldots * \mathrm{P}(\mathrm{xn} / \mathrm{Ci})$.

$\mathrm{P}(\mathrm{c} 1)=(\mathrm{P}(\mathrm{C} 1)=\mathrm{P}($ buys mobile $=$ yes $)=3 / 4=0.75$

$\mathrm{P}(\mathrm{C} 2)=\mathrm{P}($ buys mobile $=$ no $)=1 / 4=0.25$

$\mathrm{P}($ income $=$ medium $/$ buys mobile $=$ yes $)=1 / 3=0.33$

$\mathrm{P}($ income $=$ medium $/$ buys mobile $=$ no $)=1 / 1=1$

$\mathrm{P}($ credit rating $=$ fair $/$ buys mobile $=$ yes $)=1 / 3=0.33$

$\mathrm{P}($ credit rating $=$ fair $/$ buys mobile $=$ no $)=1 / 1=1$

$\mathrm{P}(\mathrm{X} /$ buys mobile $=$ yes $)=\mathrm{P}($ income $=$ medium $/$ buys mobile $=$ yes $) * \mathrm{P}($ credit rating=fair/buys mobile $=$ yes $)$

$=0.33$

$\mathrm{P}(\mathrm{X} /$ buys mobile $=\mathrm{No})=0.33$

2.1.3 Find class $C i$ that Maximizes $P(X / C i) * P(C i)$

$\mathrm{P}(\mathrm{X} /$ buys mobile $=$ yes $) * \mathrm{P}($ buys mobile $=$ yes $)=0.24$

$\mathrm{P}(\mathrm{X}$ buys mobile $=$ No $) * \mathrm{P}($ buys mobile $=$ no $)=0.08$

\subsection{4: Prediction}

Since probability of buying mobile is 0.24 which is greater than of not buying i.e. 0.08 . Therefore a person belongs to tuple $\mathrm{x}$ will buy mobile.

\subsection{Case Based Reasoning}

In cased based reasoning it classifies the case according to the past experiences. [4]There are two ways of case-based reasoning: problem solving and interpretive. Problem solving method use old solution as the solution to the new problem and it provide warning message as well.[4]In the interpretive new situation are examine in the context of old situations After the problem situation has been assessed, the best matching case is searched in the case base and an approximate solution is retrieved. Retrieved solution is considered to fit for the better new problem. The adapted solution can be evaluated either before the solution is applied to the problem or after the solution has been applied. In any case, if the accomplished result is not reasonable, the retrieved solution must be adapted again or more cases should be retrieved. If the solution was verified as correct, the new case may be added to the case base.

It can be seen as the cycle of the following four tasks:

\section{RETRIEVE:}

In this phase similar case from the case based is retrieved for a given new case.

\section{REUSE:}

To fit into the new case adapt the retrieved case.

REVISE:

Estimate the result and revise it based on how well it works.

RETAIN

Decision is made based either to retain the new case in the database or not. 


\section{COMPARING K-NN, NAIVE BAYES CLASSIFIER AND CASED BASED REASONING CLASSIFIER}

\begin{tabular}{|c|c|c|c|c|}
\hline Sl.No & Parameter & K-NN & $\begin{array}{l}\text { Naive } \\
\text { Bayes }\end{array}$ & $\begin{array}{c}\text { Case } \\
\text { based } \\
\text { reasoning } \\
\text { (lazy } \\
\text { problem- } \\
\text { solving) }\end{array}$ \\
\hline 1 & & $\begin{array}{l}\text { Object is } \\
\text { assigned to } \\
\text { the class } \\
\text { among its } \\
\mathrm{k} \text { nearest } \\
\text { neighbor. }\end{array}$ & $\begin{array}{l}\text { Probability } \\
\text { is calculated } \\
\text { and assign } \\
\text { to class with } \\
\text { the highest } \\
\text { probability }\end{array}$ & $\begin{array}{c}\text { Assign } \\
\text { case which } \\
\text { is similar } \\
\text { to a new } \\
\text { problem. }\end{array}$ \\
\hline 2 & Dataset & $\begin{array}{c}\text { It is } \\
\text { applicable } \\
\text { when } \\
\text { dataset is } \\
\text { small }\end{array}$ & $\begin{array}{l}\text { Applicable } \\
\text { when } \\
\text { dataset is } \\
\text { very large }\end{array}$ & $\begin{array}{c}\text { Applicable } \\
\text { on } \\
\text { complicate } \\
\mathrm{d} \text { as well } \\
\text { as } \\
\text { incomplete } \\
\text { cases. }\end{array}$ \\
\hline 3 & $\begin{array}{c}\text { Performanc } \\
\text { e: } \\
\text { Increasing } \\
\text { number of } \\
\text { features } \\
{[2][4]}\end{array}$ & $\begin{array}{l}\text { Increasing } \\
\text { number of } \\
\text { features } \\
\text { leads to a } \\
\text { drop of } \\
\text { performan } \\
\text { ce. }\end{array}$ & $\begin{array}{l}\text { It is perform } \\
\text { better then } \\
\mathrm{k}-\mathrm{NN} \text { with } \\
\text { the } \\
\text { increasing } \\
\text { number of } \\
\text { features }\end{array}$ & $\begin{array}{c}\text { Its } \\
\text { performan } \\
\text { ce is } \\
\text { depended } \\
\text { on the past } \\
\text { cases. }\end{array}$ \\
\hline 4 & $\begin{array}{c}\text { Performanc } \\
\text { e: } \\
\text { Increasing } \\
\text { number of } \\
\text { documents [ } \\
2][4]\end{array}$ & $\begin{array}{l}\text { It perform } \\
\text { same as } \\
\text { Naive } \\
\text { Bayes }\end{array}$ & $\begin{array}{c}\text { Performanc } \\
\text { e is almost } \\
\text { same. }\end{array}$ & $\begin{array}{c}\text { The } \\
\text { reasoner } \\
\text { does } \\
\text { his/her } \\
\text { evaluation } \\
\text { based on } \\
\text { what } \\
\text { worked in } \\
\text { the past. }\end{array}$ \\
\hline 5 & $\begin{array}{l}\text { Processing } \\
\text { time } \\
\text { Increasing } \\
\text { number of } \\
\text { documents } \\
\text { where } \\
\text { number of } \\
\text { features } \\
\text { fixed }\end{array}$ & $\begin{array}{l}\text { It depends } \\
\text { upon the } \\
\text { size of the } \\
\text { test data. It } \\
\text { takes } \\
\text { longer } \\
\text { time to } \\
\text { process as } \\
\text { compare to } \\
\text { Naive } \\
\text { Bayes. }\end{array}$ & $\begin{array}{c}\text { It also } \\
\text { depends } \\
\text { upon the } \\
\text { size of the } \\
\text { test data. } \\
\text { Compare to } \\
\text { k-NN Naive } \\
\text { Bayes } \\
\text { perform } \\
\text { better. }\end{array}$ & $\begin{array}{c}\text { processing } \\
\text { time is fast } \\
\text { as it } \\
\text { provide } \\
\text { solutions } \\
\text { to } \\
\text { problems } \\
\text { Rapidly, } \\
\text { escaping } \\
\text { the time } \\
\text { necessary } \\
\text { to derive } \\
\text { those } \\
\text { answers } \\
\text { from } \\
\text { scrape. }\end{array}$ \\
\hline
\end{tabular}

\begin{tabular}{|c|c|c|c|c|}
\hline 6. & $\begin{array}{c}\text { Processing } \\
\text { time } \\
\text { Increasing } \\
\text { number of } \\
\text { features } \\
\text { where } \\
\text { number of } \\
\text { documents } \\
\text { are fixed } \\
{[2][4]}\end{array}$ & $\begin{array}{c}\text { It takes } \\
\text { slightly } \\
\text { more } \\
\text { processing } \\
\text { time. }\end{array}$ & $\begin{array}{c}\text { It take less } \\
\text { processing } \\
\text { time } \\
\text { compare to } \\
\text { k-NN }\end{array}$ & $\begin{array}{c}\text { It takes } \\
\text { less time } \\
\text { for } \\
\text { processing } \\
\text { compare to } \\
\text { both. }\end{array}$ \\
\hline 7 & $\begin{array}{c}\text { Accuracy } \\
{[2]}\end{array}$ & $\begin{array}{c}\text { It provides } \\
\text { accuracy } \\
\text { of around } \\
72 \% .\end{array}$ & $\begin{array}{c}\text { It Provides } \\
\text { accuracy of } \\
\text { about } 85 \% .\end{array}$ & $\begin{array}{c}\text { It provides } \\
\text { accuracy } \\
\text { of about } \\
92 \% .\end{array}$ \\
\hline
\end{tabular}

\section{CONCLUSION}

The Internet has changed radically the way we live, stirring communications among people at a virtual level in several environments traversing from the professional life to social relationships. The IoT has the potential to add a new aspect to this process by allowing communications with and among smart objects. Among three algorithm that have been discussed case base reasoning is better according to study as case base reasoning reduces the computational time and solve more complicated cases and also work with the huge data as well as on minimal set of solved cases furnishing the case base. This can also apply to an incomplete model. It is also easy to maintain as it can adapt many changes in problem domain by acquiring the new cases, this eliminates some need for maintenance therefore there is only the case base(s) needs to be maintained.

\section{REFERENCES}

[1] Chang, C.L, 1974 Finding Prototypes for Nearest Neighbour Classifiers' IEEE Trans. On Computers C-23 (11), 1179-1184

[2] Hardik Maniya Mosin I, Hasan Komal, P. Patel ,2011 Comparative study of Naive Bayes Classifier and KNN for Tuberculosis International Conference on Web Services Computing.

[3] Janet L. Kolodner, 1992 An Introduction to Case-Based Reasoning' Artificial Intelligence Review 6, 3--34, Reza Entezari-Maleki

[4] Tamije Selvy P, Palanisamy V, Elakkiya S , April 2013 Evaluation Of Classification Algorithms For Disease Diagnosis Journal of Global Research in Computer Science. Volume 4, No. 4.

[5] Website K-NN Algorithm dated 12/10/2015. https://en.wikipedia.org/wiki/K-nearest_neighbors_ algorithm. 